\title{
EFFECT OF ADDING FENUGREEK SEEDS TO GOAT RATIONS AND AGE AT WEANING ON THE FATTENING PERFORMANCE AND CARCASS CHARACTERISTICS OF BALADI MALE KIDS
}

\author{
R. Salama; Sh. M. Fouda;M. A. I. El-Sysy and A.S. Gomaa \\ Al-Azhar University, Faculty of Agric., Anim. Prod. Department, Nasr city, Cairo, Egypt.
}

\section{SUMMARY}

\begin{abstract}
$\mathrm{T}$ wenty four male Baladi kids were used in a fattening trial to investigate the effect of age at weaning and fenugreek seeds supplements to fattening ration on kids performance, carcass characteristics and meat chemical composition. Newborn male Baladi kids were randomly assigned after birth to two equal groups (each of $12 \mathrm{kids}$ ). Both the two groups were randomly subdivided into two sub-weaning groups to be either weaned early ( 8 wks old age or later weaned to 16 wks old). Two sub-weaning groups (8 and $16 \mathrm{wks})$ were supplemented in their creep feeding ration $(13.0 \%$ DCP and $78.0 \%$ TDN) with $2 \%$ fenugreek seeds (FS) and served as a treated group, while the others ( $8 \& 16 \mathrm{wks})$ served as a control (nil fenugreek seeds). Male kids were offered the creep feeding ration at 3 wks old age and up to the respective weaning age, besides suckling their dams. At 16 wks old age, kids were offered a fattening ration $(12.62 \% \mathrm{CP}$ and $58 \% \mathrm{TDN})$ until $20 \mathrm{~kg}$ live body market weight, while treated groups still supplemented in their ration with $2 \%$ fenugreek seeds (FS). Male kids performance, ration digestibility, rumen liquor measurements and kids carcass characteristics and chemical composition were determined. Results obtained indicated that, supplementing fattening rations of male kids with fenugreek seeds led to increase insignificantly ration palatability and intake and improved $(\mathrm{p}<0.05)$ ration nutrients digestibility and nutritive values. Adding fenugreek seeds to fattening rations of male kids, showed positive influences in increasing $\mathrm{NH}_{3}-\mathrm{N}$ release and TVFA's production in rumen liquor, while time of measuring indicated significant differences in $\mathrm{pH}, \mathrm{NH}_{3}-\mathrm{N}$ and TVFA`s production at different times. Supplementing fattening rations with fenugreek seeds led to improve $(\mathrm{p}<0.05)$ treated male kids feed conversion ratio and accelerated $(\mathrm{p}<0.05)$ kids daily gain and to more heavier market weight i.e.: 79.95 and $82.10 \mathrm{~g} / \mathrm{h} / \mathrm{day}$ for $\mathrm{G}_{3}$ and $\mathrm{G}_{4}$ (the two supplemented rations) in compare with 67.10 and $73.03 \mathrm{~g} / \mathrm{h} /$ day for $\mathrm{G}_{1}$ and $\mathrm{G}_{2}$; (non-supplemented rations), respectively, and 23.72 and $22.12 \mathrm{~kg} v s .19 .83$ and $21.02 \mathrm{~kg} / \mathrm{h}$ final body market weight for both the two supplemented and non-supplemented rations, respectively. Fattening ration supplements and early weaning practice didn't have any significant effects on warm carcass weight in $\mathrm{kg}$ or slaughter kids dressing percentages. However both the two early fattening groups showed insignificantly heavier warm carcass weight and dressing percentages in compare with the two later weaned ones. Neither fenugreek seeds supplements nor age of kids at weaning had any significant effects on kids eye muscle chemical composition.
\end{abstract}

Keywords: Fenugreek seeds, goat rations, kids, age at weaning and carcass characteristics.

\section{INTRODUCTION}

The World Health Organization (WHO) encourages using medicinal herbs and plants (MH\&P) to substitute or minimize the use of chemicals through the global trend to go back to nature. The use of herbal galactogogues is known to have beneficial effect on milk production (Singh et al., 1991 and Tiwari et al., 1993). Using medicinal herbs and seeds as feed additives to ruminants seems to be a recent trend globally (Singh et al., 1993). The seeds of Fenugreek have been used in traditional medicine to promote lactation in lactating women (Tiran, 2003). In Egyptian folkloric medicine it is well known that fenugreek seeds are used by ancient as well as modern Egyptian women to increase milk secretion (Basha et al., 1987). Fenugreek has been shown to influence the lactation performance in ruminants. In goats, feeding $60 \mathrm{~g}$ day of fenugreek seeds powder increased milk yield without any effects on milk fat percentage (Alamer and Basiouni 2005). In buffaloes, fenugreek seeds feeding increased milk yield but without any effects on milk composition except for a tendency of lower fat content (El-Alamy et al., 2001).

Feeding costs of kids represent about $65-70 \%$ of the total current costs. Improving growth rates and marketing weights in shorter periods contributes to improve the feed efficiency and economic return. Therefore, this study was designed to investigate the effect of adding fenugreek seeds to goat rations on fattening performance and carcass characteristics of Baladi male kids. 


\section{MATERIALS AND METHODS}

The present study was carried out at the experimental farm station of the animal production department, Al-Azhar University, Nasr city, Cairo, Egypt.

After does kidding, 24 male Baladi kids were left to suckle their dams until being weaned earlier ( 8 weeks of age) or later (16 weeks of age, Table 1). Newborn kids (3 weeks old) were allowed a free excess creep feeding ration, besides suckling their dams until weaning. Starter ration (13.7 DCP\% and 78.0 TDN \%) was offered ad lib in $4 \mathrm{~mm}$ screen pelleted form. Creep feeding ration of newborn male kids consisted of $(56.5 \%$ ground yellow corn, $30 \%$ soy bean meal, $5 \%$ wheat bran, $5 \%$ molasses, $2 \%$ ground lime stone, $1 \%$ sodium chloride, $0.5 \%$ mineral mix. and vit.). On the other hand, starter ration of treated newborn male kids was supplemented with $2 \%$ fenugreek seeds powder as a partial substitute to $2 \%$ molasses.

Male kids for both the control and treated groups irrespective of age at weaning were fattened on the following ration (Table 2) until the final market weight (20 kg on the average).

Fattening ration of male kids consisted of $35 \%$ ground yellow corn, $30 \%$ bean straw, $15 \%$ wheat bran, $10 \%$ soybean meal, $2 \%$ urea, $5 \%$ molasses, $2 \%$ lime stone, and $1 \%$ sodium chloride with a total cost of $2200 \mathrm{LE} / \mathrm{ton}$. Fattening ration was offered in a pelleted form (4 mm screen) ad lib to provide (12.6\% $\mathrm{CP}$ and $58.0 \% \mathrm{TDN})$. Treated male kids group are still receiving $2 \%$ fenugreek allowances in a partial substitute to $2 \%$ bean straw until the final market live body weight (20 kg on the average). Daily feed allowance of male kids during rearing period and fattening stage ration formulation were calculated and prepared according to NRC recommendation (1981).

\section{Digestibility trails:}

Digestibility trial was conducted at the beginning of the fattening trial, while ruminal measurements were being carried out using 3 bucks/ group by the end of the study. The bucks were confined in metabolic cages for 10 days as a preliminary period, followed by another 5 days for collection of feces and urine. Rations were offered daily in two equal parts at 08:00 and 16:00 hrs. Water was offered free choice. Urine, feces and feed residuals, if any, were collected quantitatively once daily. One tenth of the representative fresh samples were daily taken and oven dried at $70^{\circ} \mathrm{C}$. Dried feed and fecal samples were kept for later proximate chemical analyses according to A.O.A.C. (1980).

Samples of ruminal fluids were collected before feeding, at 3 and 6 hours post feeding. Ruminal pH was determined immediately using digital pH meter (Orion Research Digital pH meter, model 201). Total volatile fatty acids concentrations were determined by steam distillation as described by Warner (1964) and Ammonia-nitrogen concentration $\mathrm{NH}_{3}-\mathrm{N}$ according to (Abou-Akkada and Osman, 1967).

\section{Slaughter trails:}

By the end of the fattening trail (market body weight = approximately $20 \mathrm{~kg}$ ), 3 fasted bucks were randomly chosen, according to their birth date, to be slaughtered. The carcass components were estimated as described by Colomer et al. (1987). Animals were skinned, evacuated and dressed out, while the hot carcass was dissected into four quarters. Edible offal organs (liver, heart, testes, spleen, kidney, kidney with fat and lungs) were also weighted. The rib eye area (REA) was measured in the Longissimus dorsi muscle drawn on tracing paper between the $12^{\text {th }}$ and $13^{\text {th }}$ ribs of the left half carcass. The muscle contour was outlined on plastic sheet and the area was determined through a digital planimeter, using the mean of three readings (Abdel-Moneim, 2009).

\section{Statistical Analysis:}

Data were statistically analyzed using GLM procedures using the statistical package software SAS (SAS Institute Inc., 2004, Cary, NC., USA). Significant differences among means were detected using Duncan's Multiple Range Test (Duncan, 1955). Data were analyzed using the following model:

Where:

$$
Y_{i j}=\mu+T_{i}+R_{J}+E_{i j}
$$

$\mathrm{Y}_{\mathrm{ij}}=$ the observation of the parameter

$\mu=$ overall means

$\mathrm{T}_{\mathrm{i}}=$ the effect of dietary rations

$\mathrm{R}_{\mathrm{J}}=$ the effect of replication

$E_{i j}=$ the random error term 
Egyptian J. Nutrition and Feeds (2015)

\section{RESULTS AND DISCUSSION}

\section{Digestibility coefficients and nutritive values:}

As shown in Table (3), there were insignificant differences between both the two experimental groups in their feed intake either as g DM or OM intake/ head/ day. However, the supplemented ration was insignificantly more palatable to be excessively consumed, meanwhile higher insignificant DMI and OMI were detected for the supplemented fattening ration.

As shown in the same table, supplementing the basal fattening ration by fenugreek seeds led to improve $(\mathrm{P}<0.05)$ digestibility coefficients for most of ration nutrients i.e. higher $(\mathrm{P}<0.05)$ digestibility of DM, OM, CP, CF, EE, except NFE which indicated almost similar digestibility values i.e. 60.14\% and $64.17 \%$ for the basal and supplemented rations, respectively. Similar results were reported by Petit et al. (1993), Tiwari et al. (1993), Tomar et al. (1996) and Allam et al. (1999) who found that the inclusion of fenugreek seeds in the goat' rations increased feed intake than that of control by $13.64 \%$, while Singh et al. (1991), El-Saadany et al. (1996) and Allam et al. (1999) postulated that medicinal herbs led to enhance feed digestibility.

The higher digestibility of fattening ration due to fenugreek seeds supplementation resulted consequently in positive effects on the fattening ration nutritive value. As shown in Table (3), higher $(\mathrm{P}<0.05)$ TDN\% and DCP\% values were detected for the supplemented ration i.e. 64.54 vs. 55.71\% TDN and 9.61 vs. $9.11 \%$ DCP for both supplemented and non-supplemented rations, respectively. However, it was worthy to note that supplementing the basal ration with fenugreek seeds improved $(\mathrm{P}<0.05)$ the TDN value of the ration by about $15 \%$ but to lesser extent for its DCP content (5\% only). At the same trend, Zeid (1998) found that the addition of herbal plants to the ration improved values of TDN, SV and DCP\% $(\mathrm{P}<0.05)$ compared to control ration (without additives).

\section{Rumen metabolites:}

Data presented in Table (4) showed higher $(\mathrm{P}<0.05) \mathrm{pH}$ value for the supplemented vs. basal fattening rations, i.e. 5.84 vs. 5.78, respectively. However, higher $(\mathrm{P}<0.05)$ neutral $\mathrm{pH}$ value was detected for the control ration at zero time. At three hours after feeding, $\mathrm{pH}$ values tended to be lower $(\mathrm{P}<0.05)$ with both rations indicating more acidity media, while the supplemented ration recorded higher $(\mathrm{P}<0.05)$ value in comparison with the control ration. Six hours later, both rations indicated lower $(\mathrm{P}<0.05) \mathrm{pH}$ value, but higher $(\mathrm{P}<0.05)$ than those recorded at $3 \mathrm{hrs}$ after feeding. The control ration tended to indicate higher $(\mathrm{P}<0.05) \mathrm{pH}$ value compared to the supplemented one, i.e. 5.63 vs. 5.61, while both the two rations tended to exhibit more acidity media, but lower $(\mathrm{P}<0.05)$ those values recorded at zero time. As a general remark, Fenugreek supplementation tended to have a lower $\mathrm{pH}$ value. On the other hand, time of sampling had a significant $(\mathrm{P}<0.05)$ effect on the $\mathrm{pH}$ value, being higher to approach neutral media at zero time and then tended to be more acidity at $3 \mathrm{hrs}$ and $6 \mathrm{hrs}$ after feeding. Figures obtained were 6.45 , 5.31 and 5.62 at 0,3 , and $6 \mathrm{hrs}$, respectively.

Ammonia-N concentration of the rumen liquor (Table 4) indicated significant differences due to time of sampling and supplementation. The supplemented ration recorded higher $\mathrm{NH}_{3}-\mathrm{N}$ release at different times of measuring in comparison with the control ration i.e. 30.49 vs. $29.11 \mathrm{mg} / 100 \mathrm{ml}$, respectively. On the other hand, sampling time indicated higher $\mathrm{NH}_{3}-\mathrm{N}$ release at $3 \mathrm{hrs}(33.11 \mathrm{mg} / 100 \mathrm{ml})$ and and $6 \mathrm{hrs}$ $(31.94 \mathrm{mg} / 100 \mathrm{ml})$ after feeding in comparison with those recorded at zero time $(24.36 \mathrm{mg} / 100 \mathrm{ml})$. Matching $\mathrm{NH}_{3}-\mathrm{N}$ concentration at the corresponding $\mathrm{pH}$ values at different times of measuring, indicating higher $(\mathrm{P}<0.05) \mathrm{NH}_{3}-\mathrm{N}$ production at the more acidity pH value i.e. $33.11 \mathrm{mg} / 100 \mathrm{ml}$ at $\mathrm{pH} 5.31(3 \mathrm{hrs}$ post feeding) lowered $(\mathrm{P}<0.05)$ to $31.94 \mathrm{mg} / 100 \mathrm{ml}$ at $\mathrm{pH} 5.62$ (6hrs after feeding), but only $24.36 \mathrm{mg} /$ $100 \mathrm{ml}$ at $\mathrm{pH} 6.45$ (before feeding). Such result might suggest that fenugreek seeds supplementation led to lower $(\mathrm{P}<0.05) \mathrm{pH}$ value which might lead in turn to increase $(\mathrm{P}<0.05) \mathrm{NH}_{3}-\mathrm{N}$ release. In this regard, Allam et al. (1999) found that medicinal plant seeds insignificantly decreased ruminal $\mathrm{pH}$. They noticed that ruminal $\mathrm{pH}$ values were 5.63, 5.52 and 5.61 for the control, Nigella sativa and fenugreek seeds, respectively. However, Nazar (1994) found that fenugreek and Lepidium sativum seeds raised sheep ruminal $\mathrm{pH}$ at 2 hours after feeding than those of control.

As for TVFA's production, data obtained in Table (4) indicated significant differences due to ration supplementation and also among different measuring time. The addition of fenugreek seeds led to increase $(\mathrm{P}<0.05)$ TVFA`s production as high as $13.51 \mathrm{meq} / 100 \mathrm{ml}$ at $3 \mathrm{hrs}$, then lowered $(\mathrm{P}<0.05)$ to $10.07 \mathrm{meq} / 100 \mathrm{ml}$ at $6 \mathrm{hrs}$ after feeding. Total VFA`s production before feeding recorded $11.29 \mathrm{meq} / 100$ $\mathrm{ml}$ which was higher $(\mathrm{P}<0.05)$ than the corresponding one at $6 \mathrm{hrs}$ after feeding, but lower $(\mathrm{P}<0.05)$ than those at $3 \mathrm{hrs}$ after feeding. Such result might suggest that TVFA`s concentration reached its peak at $3 \mathrm{hrs}$ after feeding then declined $(\mathrm{P}<0.05)$ with the advance time. In brief, adding fenugreek herbs to fattening ration led to increase $(\mathrm{P}<0.05)$ TVFA`s production at different measuring times. These results were in 
agreement with those reported by Abdou (2001) who found that ration containing different medicinal plant seeds (Fenugreek, Carum Carvi, Nigella Sativa and Lepidium Sativum) produced more TVFA`s than those of the control, which might be due to the better utilization of feed by a stimulated rumen microflora activity. He attributed such improvement to decreasing number and activity of antagonistic organisms; saving some important microfactors to rumen microflora as microelements, (vitamins, hormones, enzymes and /or unknown factors) which are required to improve digestion, absorption as an effective components in medicinal herbs; or might be due to inhibition of fungi growth and aflatoxin production (Allam et al., 1999); due to saponins found in fenugreek seeds. These results are in accordance with those mentioned by Singh et al. (1991) and Valdez et al. (1986) who found that medicinal herbs increased $(\mathrm{P}<0.05)$ the molar proportion of VFA production in the rumen of buffaloes

\section{Male kids Growth performance from weaning to marketing:}

As shown in Table (5), regardless of age at weaning, both rations $\left(\mathrm{G}_{3}\right.$ and $\left.\mathrm{G}_{4}\right)$ recorded significantly higher $(\mathrm{P}<0.05)$ final live body weight $(\mathrm{LBW})$, total live body weight gain $(\mathrm{TBWG})$, and faster average daily gain (ADG). However, $\mathrm{G}_{4}$ as an earlier supplemented fattened group surpassed the other experimental groups in growth performance and recorded $23.72 \mathrm{~kg}$ final LBW, 9.19kg TBWG and 82.10 $\mathrm{g} / \mathrm{h} /$ day $\mathrm{ADG}$, but without significant difference with $\mathrm{G}_{3}$. Such result might confirm the positive influences of fenugreek seeds supplementation on digestibility and nutritive value (Table 3), which in turn led to increase ration palatability and intake, improved $(\mathrm{P}<0.05)$ rumen liquor characteristics (Table 4) and hence accelerated male kids growth performance.

On the other hand, both earlier weaned groups, $\mathrm{G}_{2}$ and $\mathrm{G}_{4}$ surpassed the corresponding later weaned ones $\left(G_{1}\right.$ and $\left.G_{3}\right)$ in such criteria. Such results may lead to favour both of fenugreek seeds supplementation and early weaning practice in order to improve kids growth performance. Data of feed intake and feed conversion (Table 5) indicated the insignificant differences among different fattened male groups in daily DMI, although both the two supplemented rations groups indicated insignificantly an efficient feed utilization of food in comparison with the two unsupplemented ones, i.e. 10.01 and $11.24 \mathrm{~kg}$ DMI $\mathrm{kg}$ gain for $\mathrm{G}_{4}$ and $\mathrm{G}_{3}$ and 6.02 and $6.76 \mathrm{~kg}$ TDNI/ $\mathrm{kg}$ gain for both the two groups, respectively.

regarding the effect of age at weaning on male kids feed intake and conversion ratio, it was also shown a higher insignificant feed conversion ratio for the early male kids groups $\left(G_{2}\right.$ and $\left.G_{4}\right)$ in comparison with the corresponding later weaned ones $\left(\mathrm{G}_{1}\right.$ and $\left.\mathrm{G}_{3}\right)$, respectively. It was of interest to point out to lower feed conversion efficiency as a general status for fattened male Baladi kids which ranged between $10.0 \mathrm{~kg}$ DMI/ $\mathrm{kg}$ gain for the most efficient group $\left(\mathrm{G}_{4}\right)$ to $13.74 \mathrm{~kg}$ DMI $/ \mathrm{kg}$ gain for the least efficient one $\left(\mathrm{G}_{1}\right)$. Such evident might be mainly related to the slower growth performance of the specie itself rather than other different factors.

Growth performance for fattened male kids during the most faster period of their early life are being contribute to an abundant feed (milk and solid ration) (Salama et al., 2012).

From an economic point of view, both supplemented fattened groups $\left(\mathrm{G}_{3}\right.$ and $\left.\mathrm{G}_{4}\right)$ recorded lower $(\mathrm{P}<0.05)$ feed costs $/ \mathrm{kg}$ gain i.e. 24.72 and $22.02 \mathrm{LE} / \mathrm{kg}$ gain and higher $(\mathrm{P}<0.05)$ net profit values $(11.28$ and $13.98 \mathrm{LE} / \mathrm{kg}$ gain). The same trend was also detected with the two early weaning groups, which favored both of $\mathrm{G}_{2}$ and $\mathrm{G}_{4}$ to record lower $(\mathrm{P}<0.05)$ feed costs and higher $(\mathrm{P}<0.05)$ net profit values in comparison with both of $\mathrm{G}_{1}$ and $\mathrm{G}_{3}$ (the later weaned ones) (Table 5).

\section{Effect of adding Fenugreek seeds and age at weaning on kids carcass characteristics and meat chemical composition.}

As shown in Table (6), there were insignificant differences among different experimental groups in warm carcass weight with or without edible offal organs. The same findings were also observed in kids dressing percentage in both the two forms.

Dressing percentage in both terms i.e. with and without edible offal organs indicated that neither fenugreek seeds supplementation nor age of kids at weaning have any significant effect on improving such values. Both the two supplemented feed groups indicated insignificant warm carcass weight in $\mathrm{kg}$ and dressing percentage values. Such result may lead to suggest that, although fenugreek seeds supplementation had a positive impact in improving $(\mathrm{P}<0.05)$ rations palatability, nutrients digestibility, kids growth performance and feed utilization which lead in turn to an economic feed utilization at lower $(\mathrm{P}<0.05)$ feed costs, but it did not affect kids slaughter performance. Meanwhile, its positive effects was only evident detected and pronounced in decreasing $(\mathrm{P}<0.05)$ feed costs of the final survival products (kids live body weight) i.e. an efficient feed utilization at an economic price.

On the contrary, early weaning of male kids led to higher insignificant dressing percentage in both the two dressing terms. Figures obtained were 48.216 and $52.03 \%$ for the early weaned supplemented group $\left(\mathrm{G}_{4}\right)$ in comparison with 46.34 and $50.813 \%$ for the late weaned supplemented ones. and, 50.74 and 
$55.36 \% v s .49 .49$ and 54.19 for both of $\mathrm{G}_{2}$ and $\mathrm{G}_{1}$ (an earlier weaned unsupplemented kids $v s$. the later weaned unsupplemented ones, respectively).

Such results might favored early weaning rather than fenugreek seeds supplementation as positive insignificant agent in improving insignificantly male kid's carcass dressing percentage. Such early weaning practice as well as the late weaning or might be surpassed it in improving carcass performance of fattened male kids, and did not have any negative effects on either the survival products (marketing kids at lower feed costs) or carcass characteristics.

Early weaning of kids (at 8 weeks of age) provides also a secondary advantage due to its positive influence in sparing more time for their dams to restore weight and health and in turn led to more productive and reproductive cycles at relatively more comfortable status.

\section{Effect of adding Fenugreek seeds to fattening rations and age at weaning on the chemical composition of carcass lean tissues.}

Data obtained in Table (7) pointed out to insignificant differences among the experimental groups in meat chemical composition. However, it was noticed a similar moisture content, ranged between $75.12 \%$ for $\mathrm{G}_{1}$ to $76.66 \%$ for $\mathrm{G}_{3}$; similar $\mathrm{CP} \%$ content, ranged between $19.81 \%$ for $\mathrm{G}_{4}$ to $21.71 \%$ for $\mathrm{G} 1$; $\mathrm{EE}$ ranged between $2.15 \%$ for $\mathrm{G}_{3}$ to $2.86 \%$ for $\mathrm{G}_{1}$; ash content ranged between 0.717 to $0.863 \%$ for both $\mathrm{G}_{3}$ and $\mathrm{G}_{4}$, respectively. As a general evidence and with lack of significancy among different experimental groups in meat chemical composition of fattened male kids, it was worthy to conclude that: 1) such figures obtained might be a general features of fattened meat kids at an average market live body weight of $20 \mathrm{~kg}$ and an average 7.5 months of age; 2) At such age and live body weight kids meat contain on the average $75 \%$ moisture, $20 \% \mathrm{CP}, 2.5 \% \mathrm{EE}$ and less than $1 \%$ ash content; 3 ) No obvious evidence was detected to favor neither the nutritional feed additives (fenugreek seeds) nor the weaning practice to have any pronounced influences on kid's meat chemical composition.

\section{CONCLUSIONS}

From an economic point of view, it could be concluded that supplementing fattening rations of male kids with fenugreek seeds led to increase insignificantly ration palatability and intake, improved their digestibility, and nutritive values. Early weaning led to positive effects on accelerating kids growth performance. Supplementing fattening rations with fenugreek seeds led to accelerate kids daily gain and to more heavier market weight. On the other hand, supplementing fattening ration with fenugreek seeds and early weaning practice did not affect nietehr male kids warm carcass weight or kids dressing percentages.

\section{REFERENCES}

AOAC (1980). Association of Official Analytical Chemists. Official methods of analysis of the Association of Official Analytical Chemists. $13^{\text {th }}$ ed. Washington, DC.

Abdel-Moneim, A.Y. (2009). Body and carcass characteristics of Ossimi, Barki and Rahmani ram lambs raised under intensive production system. Egypt. J. Sheep Goat. Sci., 4:1-16.

Abdou. M.M.A. (2001). Effect of some herbal plants as additives on performance of lactating animals. $\mathrm{Ph}$. D. Thesis, Fac. of agric., Cairo Univ. Egypt.

Abou-Akkada, A.R. and H. El Sayed Osman (1967). The use of ruminal ammonia and blood urea as an index of the nutritive value of protein in some food-stuffs. The Journal of Agri. Sci., 69: 25-31.

Alamer, M. and G. Basiouni (2005). Feeding effects of fenugreek seeds (Trigonella foenum-graecum L.) on lactation performance, some plasma constituents and growth hormone level in goats. Pak. J. Biol. Sci., 25:28-46.

Allam, S.M.; Hoda M. El Hosseiny; A.M. Abdel Gawad; S.A. El-Saadany and A.M.M. Zeid (1999). Medicinal herbs and plants as feed additives for ruminants. 1. Effect of using some medicinal herbs and plants as feed additives on Zaraibi goats performance. Egypt. J. Nutrition and feeds, 2, (special Issue): $349-365$.

Basha, L.A.; M. Rokaya; M. Husein; M. Badawi and A.M. Abdalla (1987). The influence of (TrigonellaFoenum- Graecum) on prolactin release in female Albino rats during different phases of reproductive life. J. Drug Res. Egypt., 17:1-2. 
Colomer, F.; Morand, Fehr, P. and A.H. kirton (1987). Standard methods and procedures for goats carcass evaluation jointing and tissue separation. Livestock production Sci., 17: 149-159.

Duncan, D.B. (1955). Multiple range and Multiple F-test. Biometrics, 11:42.

El-Alamy. H.A.; H.M. Khattab; S.A. El-Nor; F.A.F Salam and M.M.A. Abdou (2001). Milk production response to supplementing rations with some medical herbs of lactating buffaloes. 8th Egyptian Conference for Dairy Science and Technology, Research Papers II. pp: 675-686.

El-Saadany, S.A.; M. Abd El-Momin; F.M. abo-Ammou and E.I. Shehata (1996). Effect of using medicinal herbs as feed supplements on ruminants performance I-Effect of using medicinal herbs as a milk stimulant feed supplements on sheep ewes and lambs performance. Egypt J. Appl.Sci., 11:41-56.

Nazar, F.A.A. (1994). The use of some medicinal plants as ruminal tonics of sheep M. Sc. Thesis, Fac. of vet. med., Moshtohor, Zagazig Univ., Egypt.

NRC (1981). Nutrition requirements of goats in temperate and tropical contries. National Academy press, Washington D.C., USA.

Petit, P.; Y. Sauvaire; G. Ponsis; M. Monteghetti; A. Fav and G. Ribes (1993). Effect of a fenugreek seeds extract on feeding behavior in rat metabolic- endocrine correlate. Pharmacology Biochemistry and Behavior J., 45(2):369-374.

Salama, R.; M.M. Shaaban; A.A. Hegazi; SH.M. Fouda; M.A. I. El Sysy and A.S. Gomaa (2012). Impact of supplementing does ration with Fenugreek seeds on milk yield and growth performance. Egyptian J. of Nutr. and feeds, 15:1(special Issue).

SAS, (2004). SAS / STAT 9.1.3 User's Guide. Statistical Analysis System. Institute Inc., Cary, NC, USA.

Singh, N.; R. Kumari; R.S. Yada; M.A. Akbar and B.P. Sengupta (1991). Effect of some commonly used galactagogues on milk production and biogenic amines in buffaloes Indian Vet. Med. J., (15): 20-24.

Singh, N.; M.A. Akbar and R. Kumari (1993). Effect of some commonly used galactagogues on different blood biochemical constituents of lactating buffaloes. Indian Vet. J., 70:441-444.

Tiran, D. (2003). The use of fenugreek for breast feeding women. Complem. Ther. Nurs. Midwif, 9: 155156.

Tiwari, S.; P.R. Lal; S.P. Arrora and M.P. Narange (1993). Effect of feeding anise as herb combination on milk production in cross bred cows. Indian. J. Anim. Nutr., 10:115-117.

Tomar, K.S.; V.P. Singh and R.S. Yadav (1996). Effect of feeding maithy (Trigonella-Foenum-Graecum) and chanrasoor (Lepidium Sativium) seeds on milk and blood constituents of Murrah buffaloes. Indian J. Anim. Sci. 66, (11):1192-1193.

Valdez, F.R.; L.J. Bush; A.L. Goetsch and F.N. Owens (1986). Effect of steroidal sapogenins on ruminal fermentation and on production of lactating dairy cows. J. Dairy Sci., 69:1568-1575.

Warner, A.I. (1964). Production of volatile fatty acids in the rumen. Methods of measurement. Nutr. Abst. and. Rev., 334-339.

Zeid, A.M.M. (1998). Effect of using medicinal plant on goats performance, Ph.D. Thesis, Fac. Of Agric., Cairo, Egypt. 
Table (1). Experimental design.

\begin{tabular}{lllll}
\hline \multirow{2}{*}{ Starter Rations } & $\mathrm{G}_{1}$ & $\mathrm{G}_{2}$ & $\mathrm{G}_{3}$ & $\mathrm{G}_{4}$ \\
\cline { 2 - 5 } & Control & \multicolumn{3}{l}{ Control + (FS) * } \\
\hline Weaning age (wks) & 16 & 8 & 16 & 8 \\
No. of weaned kids & 6 & 6 & 6 & 6 \\
\hline
\end{tabular}

*FS = fenugreek seeds (Trigonella foenum Graecum)

Table (2) Chemical composition of the fattening rations.

\begin{tabular}{|c|c|c|c|c|c|c|c|c|}
\hline Items & & $\mathrm{DM}$ & $\mathrm{OM}$ & $\mathrm{CP}$ & $\mathrm{CF}$ & $\mathrm{EE}$ & $\mathrm{NFE}$ & Ash \\
\hline \multirow{2}{*}{ 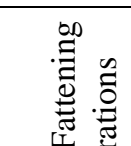 } & Control & 88.98 & 86.51 & 12.62 & 16.72 & 2.11 & 55.06 & 13.49 \\
\hline & $\begin{array}{l}\text { Treatment } \\
(\text { control+ FS) }\end{array}$ & 89.28 & 86.88 & 12.99 & 16.36 & 2.48 & 55.05 & 13.12 \\
\hline
\end{tabular}

Table (3). Effect of adding fenugreek seeds to male goats (bucks) fattening ration on dry matter intake, digestibility coefficients and rations nutritive values.

\begin{tabular}{lll}
\hline Items & Control & Treatment* \\
\hline DM intake $(\mathrm{g} / \mathrm{h})$ & $1414 \pm 73.07$ & $1564 \pm 40.89$ \\
OM intake $(\mathrm{g} / \mathrm{h})$ & $1223 \pm 63.18$ & $1359 \pm 35.52$ \\
Digestibility coefficients $(\%)$ & & \\
DM & $59.33^{\mathrm{b}} \pm 1.58$ & $63.81^{\mathrm{a}} \pm 0.72$ \\
OM & $62.51^{\mathrm{b}} \pm 1.37$ & $64.75^{\mathrm{a}} \pm 1.55$ \\
$\mathrm{CP}$ & $72.13^{\mathrm{b}} \pm 1.51$ & $74.16^{\mathrm{a}} \pm 1.25$ \\
$\mathrm{CF}$ & $57.12^{\mathrm{b}} \pm 1.11$ & $59.21^{\mathrm{a}} \pm 1.02$ \\
EE & $83.41^{\mathrm{b}} \pm 1.44$ & $89.11^{\mathrm{a}} \pm 0.95$ \\
NFE & $60.14^{ \pm} \pm 1.52$ & $64.17^{ \pm} \pm 1.12$ \\
Nutritive value $(\%)$ & & \\
TDN & $55.71^{\mathrm{b}} \pm 1.27$ & $64.54^{\mathrm{a}} \pm 2.74$ \\
DCP & $9.11^{\mathrm{b}} \pm 0.31$ & $9.61^{\mathrm{a}} \pm 0.17$ \\
\hline
\end{tabular}

$a, b$ small letters, in the same row indicated significant difference $(p \leq 0.05)$

Treatment; means control plus Fenugreek seeds (Trigonella foenum-graecum)

Table (4). Effect of adding fenugreek seeds to fattening ration on ruminal PH, ammonia- nitrogen $(\mathrm{mg} / 100 \mathrm{ml})$ and total volatile fatty acids (meq $/ 100 \mathrm{ml})$.

\begin{tabular}{|c|c|c|c|c|}
\hline \multirow[t]{2}{*}{ Items } & \multirow[t]{2}{*}{ Time (hrs) } & \multicolumn{3}{|c|}{ Experimental fattening rations } \\
\hline & & control & Treated & Overall Mean \\
\hline \multirow[t]{4}{*}{$\mathrm{pH}$ Values } & 0 & $6.47^{\mathrm{a}} \pm 0.005$ & $6.43^{b} \pm 0.003$ & $6.45^{\mathrm{A}} \pm 0.11$ \\
\hline & 3 & $5.25^{\mathrm{b}} \pm 0.010$ & $5.36^{\mathrm{a}} \pm 0.010$ & $5.31^{\mathrm{C}} \pm 0.19$ \\
\hline & 6 & $5.63^{\mathrm{a}} \pm 0.011$ & $5.61^{\mathrm{b}} \pm 0.011$ & $5.62^{\mathrm{B}} \pm 0.09$ \\
\hline & Overall mean & $5.78^{b} \pm 0.03$ & $5.84^{\mathrm{a}} \pm 0.08$ & \\
\hline \multirow{4}{*}{$\begin{array}{l}\text { Ammonia } \\
(\mathrm{mg} / 100 \mathrm{ml})\end{array}$} & 0 & $23.59^{\mathrm{b}} \pm 0.005$ & $25.11^{\mathrm{a}} \pm 0.005$ & $24.36^{\mathrm{C}} \pm 0.04$ \\
\hline & 3 & $32.63^{\mathrm{b}} \pm 0.010$ & $33.57^{\mathrm{a}} \pm 0.010$ & $33.11^{\mathrm{A}} \pm 0.12$ \\
\hline & 6 & $31.08^{\mathrm{b}} \pm 0.011$ & $32.81^{\mathrm{a}} \pm 0.011$ & $31.94^{\mathrm{B}} \pm 0.03$ \\
\hline & Overall mean & $29.11^{b} \pm 0.18$ & $30.49^{\mathrm{a}} \pm 0.15$ & \\
\hline VFA`s & 0 & $10.95^{\mathrm{b}} \pm 0.005$ & $11.63^{\mathrm{a}} \pm 0.005$ & $11.29^{\mathrm{B}} \pm 0.05$ \\
\hline \multirow[t]{3}{*}{$(\mathrm{meq} / 100 \mathrm{ml})$} & 3 & $13.15^{\mathrm{b}} \pm 0.010$ & $13.88^{\mathrm{a}} \pm 0.010$ & $13.51^{\mathrm{A}} \pm 0.13$ \\
\hline & 6 & $9.79^{b} \pm 0.03$ & $10.36^{\mathrm{a}} \pm 0.011$ & $10.07^{\mathrm{C}} \pm 0.07$ \\
\hline & Overall mean & $11.29^{\mathrm{b}} \pm 0.12$ & $11.95^{\mathrm{a}} \pm 0.14$ & \\
\hline
\end{tabular}

Different small litters within the same row and the capital ones in the same column indicated significant difference $(p \leq 0.05)$. 
Table (5). Effect of adding (FS) herbs to goat rations on male kids performance from weaning to marketing (112-224 days age)

\begin{tabular}{|c|c|c|c|c|}
\hline Items & $\mathrm{G}_{1}$ & $\mathrm{G}_{2}$ & $\mathrm{G}_{3}$ & $\mathrm{G}_{4}$ \\
\hline No. of weaned kids & 6 & 6 & 6 & 6 \\
\hline Initial live B.W (kg) & 12.32 & 13.02 & 13.17 & 14.51 \\
\hline Final live B.W (kg) & $19.83^{\mathrm{d}} \pm 0.12$ & $21.20^{c} \pm 0.55$ & $22.12^{\mathrm{b}} \pm 0.48$ & $23.72^{\mathrm{a}} \pm 0.95$ \\
\hline Total gain $(\mathrm{Kg})$ & $7.51^{\mathrm{c}} \pm 0.04$ & $8.18^{b} \pm 0.11$ & $8.95^{\mathrm{a}} \pm 0.51$ & $9.19^{\mathrm{a}} \pm 0.32$ \\
\hline Daily gain* (gm) & $67.10^{c} \pm 0.37$ & $73.03^{b} \pm 0.91$ & $79.95^{\mathrm{a}} \pm 4.4$ & $82.10^{\mathrm{a}} \pm 2.9$ \\
\hline \multicolumn{5}{|l|}{ Feed intake as: } \\
\hline DMI (gm) & 921.8 & 920.5 & 898.78 & 821.91 \\
\hline TDNI (gm) & 535.6 & 534.95 & 540.2 & 494 \\
\hline \multicolumn{5}{|l|}{ Feed conversion } \\
\hline DMI $(\mathrm{kg}) / \mathrm{kg}$ gain & 13.74 & 12.6 & 11.24 & 10.01 \\
\hline TDNI $(\mathrm{kg}) / \mathrm{kg}$ gain & 7.98 & 7.32 & 6.76 & 6.02 \\
\hline Cost of feeding** LE/ $\mathrm{kg}$ gain & $30.22^{\mathrm{a}} \pm 0.20$ & $27.72^{\mathrm{a}} \pm 0.61$ & $24.72^{b} \pm 0.71$ & $22.02^{\mathrm{b}} \pm 0.32$ \\
\hline Net profit / kg gain (LE)*** & $5.78^{\mathrm{d}} \pm 0.20$ & $8.28^{c} \pm 0.61$ & $11.28^{\mathrm{b}} \pm 0.67$ & $13.98^{\mathrm{a}} \pm 0.32$ \\
\hline \multicolumn{5}{|c|}{$\begin{array}{l}\text { Different small letters within the same row indicated significant differences }(p \leq 0.05) \\
* \text { Fattening period }=112 \text { days } \\
* * \text { Costs of } 1 \mathrm{~kg} \text { feed }=2200 \mathrm{LE} / \text { ton in }(2013) \\
\text { * Net profit }=\text { selling market price } \mathrm{kg}(\mathrm{LBW})-\text { feed costs } / \mathrm{kg} \text { gain } \\
\text { Selling market price } / \mathrm{kg} \text { live } B W=36 \mathrm{LE}(2013)\end{array}$} \\
\hline
\end{tabular}

Table (6). Effect of Fenugreek seeds supplement to goat rations and age at weaning on carcass characteristics of fattened male kids.

\begin{tabular}{lllll}
\hline Item & $\mathrm{G}_{1}$ & $\mathrm{G}_{2}$ & $\mathrm{G}_{3}$ & $\mathrm{G}_{4}$ \\
\hline Fasting live Body Weight (kg) & $20.00 \pm 1.70$ & $22 \pm 1.40$ & $24.3 \pm 1.10$ & $22.50 \pm 2.60$ \\
Warm carcass (kg) & $9.95 \pm 1.40$ & $11.16 \pm 0.30$ & $11.22 \pm 0.50$ & $10.45 \pm 1.60$ \\
Warm carcass Including edible offal's (kg) & $10.88 \pm 1.40$ & $12.18 \pm 0.40$ & $12.31 \pm 0.50$ & $11.52 \pm 1.80$ \\
Dressing \%* & $49.49 \pm 5.20$ & $50.74 \pm 2.4$ & $46.34 \pm 0.80$ & $48.22 \pm 7.10$ \\
Dressing \%** & $54.19 \pm 4.10$ & $55.36 \pm 7.1$ & $50.81 \pm 4.00$ & $52.03 \pm 8.50$ \\
\hline * Carcass weight without offal organs & & & & \\
** Carcass weight including offals & & & &
\end{tabular}

Table (7). Effect of adding (FS) to fattening rations on the chemical composition of the eye muscle between the $12^{\text {th }}$ and $13^{\text {th }}$ ribs (on DM basis $\%$ ).

\begin{tabular}{lllll}
\hline \multirow{2}{*}{ Chemical composition $\%$} & \multicolumn{4}{c}{ EXP. Rations } \\
\cline { 2 - 5 } & $\mathrm{G}_{1}$ & $\mathrm{G}_{2}$ & $\mathrm{G}_{3}$ & $\mathrm{G}_{4}$ \\
\hline Moisture & $75.12 \pm 1.742$ & $75.67 \pm 0.067$ & $76.66 \pm 0.725$ & $76.60 \pm 0.244$ \\
CP & $21.71 \pm 1.49$ & $21.15 \pm 0.147$ & $20.07 \pm 0.722$ & $19.81 \pm 0.384$ \\
EE & $2.86 \pm 0.344$ & $2.417 \pm 0.207$ & $2.15 \pm 0.079$ & $2.72 \pm 0.232$ \\
Ash & $0.847 \pm 0.847$ & $0.763 \pm 0.107$ & $0.717 \pm 0.121$ & $0.863 \pm 0.041$ \\
\hline
\end{tabular}




\author{
رضا سلامه ، شوقي مصباح فوده ، محمود عبدالفتاح السيسي، علي سمير جمعة \\ قسم الإنتاج الحيواني ، كلية الزراعة ، جامعة الأزهر ، مدينة نصر ، الثقاهرة
}

استخدم في هذه التجربة 24 من ذكور الماعز البلدي في تجربة تسمين، بهدف دراسة تأثير العمر عند الفطام وأثر تدعيم علائق

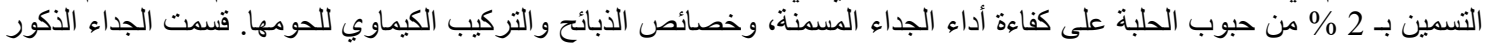

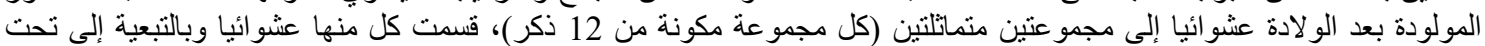

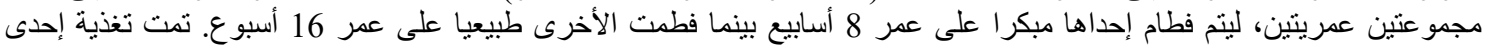

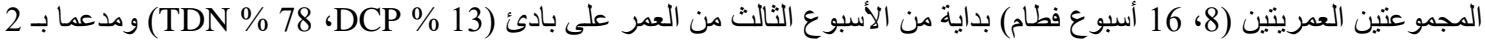

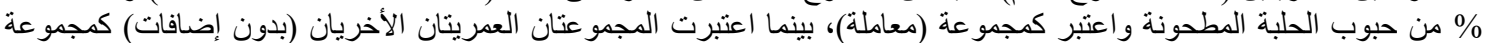

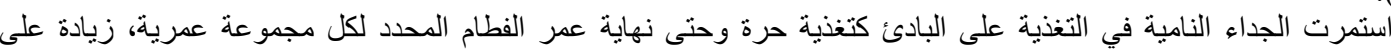

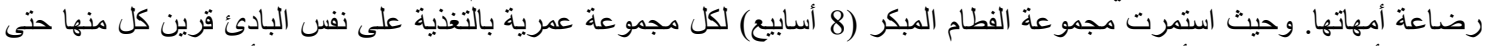

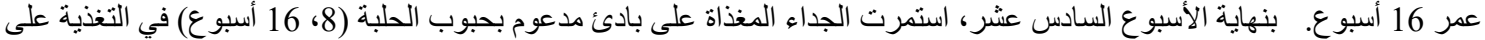

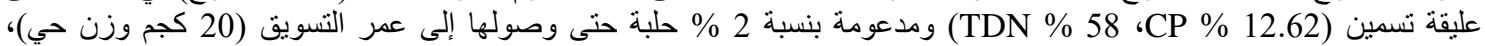

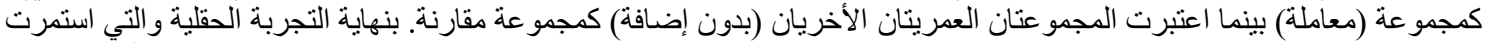

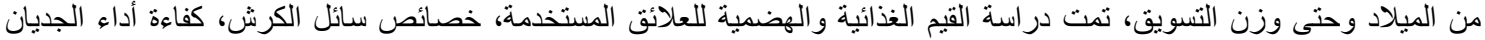

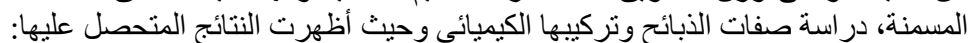

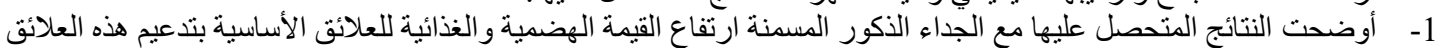

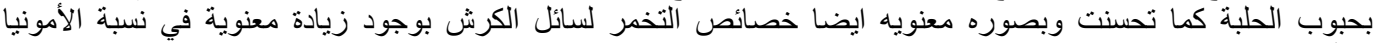

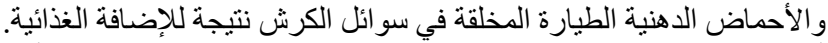

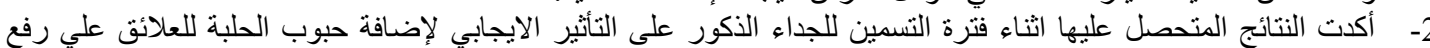

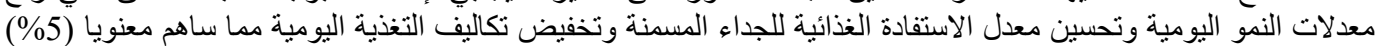
في زيادة صافي الربح لعملية التسمين.

3- أوضحت النتائج عموما أهمية تطبيق نظام الربة الفطام المبكر على عمر 8 أسابيع للجداء الرضيعة_حيث لم تكن لله تأثيرات سلبية

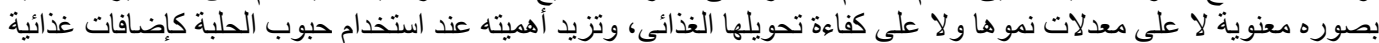
في العلائق.

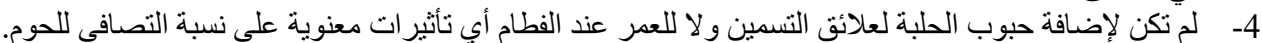

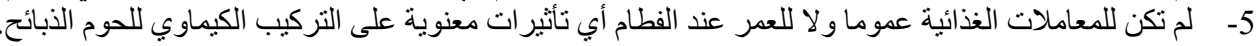

1- "فانه يوصى باستخدام حبوب الحلبة كإضافة غذائية غير مكلفه وبالمعدل السابق ذكره 2 \% م من حجم العليقة في علائق ذكور

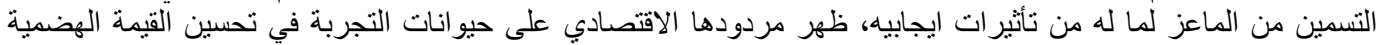

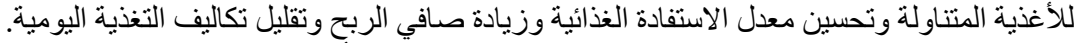

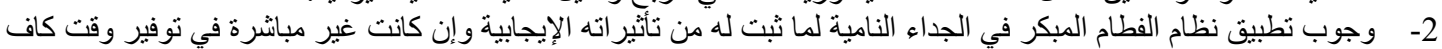

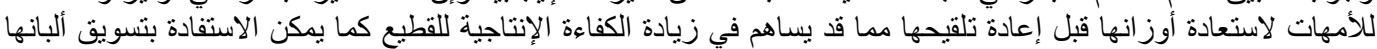

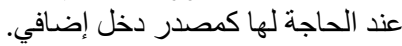

